\title{
Ability, academic climate, and going abroad for work or pursuing a PhD
}

Citation for published version (APA):

Bertrand - Cloodt, D., Cörvers, F., \& Heijke, H. (2017). Ability, academic climate, and going abroad for work or pursuing a PhD. Cesifo Economic Studies, 63(1), 119-140. https://doi.org/10.1093/cesifo/ifw015

Document status and date:

Published: 01/03/2017

DOI:

10.1093/cesifo/ifw015

Document Version:

Publisher's PDF, also known as Version of record

Document license:

Taverne

Please check the document version of this publication:

- A submitted manuscript is the version of the article upon submission and before peer-review. There can be important differences between the submitted version and the official published version of record.

People interested in the research are advised to contact the author for the final version of the publication, or visit the DOI to the publisher's website.

- The final author version and the galley proof are versions of the publication after peer review.

- The final published version features the final layout of the paper including the volume, issue and page numbers.

Link to publication

\footnotetext{
General rights rights.

- You may freely distribute the URL identifying the publication in the public portal. please follow below link for the End User Agreement:

www.umlib.nl/taverne-license

Take down policy

If you believe that this document breaches copyright please contact us at:

repository@maastrichtuniversity.nl

providing details and we will investigate your claim.
}

Copyright and moral rights for the publications made accessible in the public portal are retained by the authors and/or other copyright owners and it is a condition of accessing publications that users recognise and abide by the legal requirements associated with these

- Users may download and print one copy of any publication from the public portal for the purpose of private study or research.

- You may not further distribute the material or use it for any profit-making activity or commercial gain

If the publication is distributed under the terms of Article $25 \mathrm{fa}$ of the Dutch Copyright Act, indicated by the "Taverne" license above, 


\title{
Ability, Academic Climate, and Going Abroad for Work or Pursuing a PhD
}

\section{Daniëlle Bertrand-Cloodt* , Frank Cörvers ${ }^{\dagger}$ and Hans Heijke ${ }^{\ddagger}$}

${ }^{*}$ Research Centre for Education and the Labour Market (ROA), Maastricht University, Maastricht, Netherlands. e-mail: d.cloodt@alumni.maastrichtuniversity.nl, 'Department of Economics II, ROA, Maastricht University, Maastricht, Netherlands; Research Institute for Flexicurity, Labour Market Dynamics and Social Cohesion (ReflecT), Tilburg University, Tilburg, Netherlands. e-mail: frank.corvers@maastrichtuniversity.nl and ${ }^{\ddagger}$ Department of Economics II, ROA, Maastricht University, Maastricht, Netherlands. e-mail: h.heijke@maastrichtuniversity.nl

\begin{abstract}
We investigate whether highly able students are being creamed off from Dutch universities. Therefore, we examine the relation between ability and the destination of recent graduates of Dutch universities. Students can choose to continue their academic career by investing in a PhD degree instead of working, taking into account that both options can be realized in the Netherlands as well as abroad. Using a data set of workers and PhD students who recently graduated from Dutch universities, we simultaneously estimate two probit equations, one for the migration decision and one for the choice between working and pursuing a PhD. We take into account that both decisions can be affected by the climates in certain fields of study and universities to promote going abroad and starting a PhD. Our findings indicate that highly able graduates are significantly more likely than average graduates to go abroad. They also invest more often in a PhD programme, which is positively correlated with their likelihood to go abroad. The odds of going abroad and participating in a $\mathrm{PhD}$ programme are shown to be associated with control variables indexing the climates promoting going abroad and starting PhD study (JEL codes: F22, I23).
\end{abstract}

Key words: brain drain, international migration, university graduate, $\mathrm{PhD}$ study, academic climate

\section{Introduction}

Knowledge is becoming a main source of wealth for nations, businesses, and people (Machlup 1962; Lucas 1988; Castells 1996; Harris 2001; Rodrigues 2002). Therefore, more and more resources are devoted to the production of knowledge. Within the process of knowledge generation, universities play a key role, being exclusive producers of knowledge and educators of the highly talented (Lindley 2002; Clotfelter 2010). The conduct of fundamental and applied research universities gives them a competitive edge; they are the nursery of the most talented. By transferring their knowledge to students, universities 
prepare them for a professional career in which they apply their acquired knowledge to work or conduct research that generates new knowledge.

However, individuals who embody knowledge are scarce. If a domestic supply of knowledge does not satisfy demand, individuals embodying knowledge or knowledge-generating capacities may be transferred from other countries (Williams 2006). This has been illustrated by Black and Stephan (2010) and Stuen et al. (2012), who find that foreign-born and foreign-trained graduates, $\mathrm{PhD}$ students, and postdoctoral scholars significantly contribute to the productivity of science and engineering departments at universities in the USA. Park (2004) analyses the relevance of cross-border flows of young people for international knowledge transmission. The author finds evidence that international student flows across economies are a channel of research and development (R\&D) spillover. According to Coe and Helpman (1995), such spillover is crucial for domestic productivity growth. Empirical evidence by Stephan and Levin (2001), Chellaraj et al. (2006), and Hunt and GauthierLoiselle (2010) demonstrates the strong positive impact of both foreign graduate students and skilled immigrants on patenting and innovation in the US science and engineering research. Therefore, it is not surprising that highly talented university graduates are recruited in the race for a competitive edge in the production of knowledge (Clotfelter 2010; Boeri et al. 2012).

This article explores whether the Netherlands is indeed losing its highly able university graduates as they decide to migrate abroad. By analysing this brain drain, we examine the relation between graduates' abilities, indicated by their average master's degree grade, and their decision to go abroad. Based on the idea of the positive selection of migrants with respect to their skills (Beine et al., 2001; Saint-Paul 2008; Grogger and Hanson 2011), highly able graduates are expected to be more susceptible to going abroad than average graduates. We also expect the decision to go abroad to be correlated with the choice of what to do after graduation, that is, search for a regular job or enrol in a PhD programme. Highly able graduates are expected to be more susceptible to pursuing a $\mathrm{PhD}$, which can further raise their chances of going abroad (Docquier and Rapoport 2012). Therefore, we take into account the choice between working and pursuing a $\mathrm{PhD}$ along with the migration decision. In summary, in this article we determine whether highly able students from Dutch universities are being creamed off, since we expect more talented graduates to be more eligible for a $\mathrm{PhD}$ track and more susceptible to going abroad.

We consider the brain drain of Dutch graduates as one of the components of a much wider dynamic process of brain exchange, brain circulation, and long-term brain migration. The brain drain we analyse concerns the-at least temporary-loss of Dutch highly able graduates to other countries, whereas Dutch society invested a lot in their higher education. Information from diverse sources indicates that the flows of students to and from the Netherlands tend to rise (for example, CPB 2012). From the data set used for our empirical analysis, we derive that the number of foreign students graduating and staying in the Netherlands is $12 \%$ higher than the number of Dutch graduates going abroad. The brain exchange is further demonstrated by the $12 \%$ share of foreign students in the total number of university students in the Netherlands (CPB 2012) and the $40 \%$ share of foreign master's graduates pursuing a $\mathrm{PhD}$ in the Netherlands (Rud et al. 2015).

It is interesting to note that the academic environment of graduates can fulfil the same function as an international network that helps or stimulates them to go abroad as cultural or family connections for the low skilled. The international dimension of the academic climate of study programmes at universities could therefore be a driving factor behind the 
emigration of graduates. Gross and Schmitt (2006) show that, within a group of migrants to France, the low skilled are more driven by network effects (cultural clustering) than the high skilled. Going abroad is an investment in future opportunities that can raise returns during working life, whereas network effects can lower the costs of this investment. The socalled network/diaspora externalities of migrant networks lower the information and search costs of newcomers and provide them with financial support. Beine et al. (2011) show that larger diasporas and lower migration costs disproportionally increase the migration flows of the low skilled relative to the high skilled.

The academic environment surrounding students can affect the decision to pursue a $\mathrm{PhD}$, too. The research climate embodied by specific universities and studies towards pursuing a $\mathrm{PhD}$ can stimulate recent graduates to enrol as $\mathrm{PhD}$ students. We control for the climate promoting going abroad and the climate promoting pursuing a $\mathrm{PhD}$, since these may be strong stimuli in the investment decisions of graduates, particularly among the highly able.

We develop a model of two simultaneous probit equations in which migration and additional training due to starting a $\mathrm{PhD}$ programme are analysed, taking into account that graduates' choices are simultaneously made and affected by the academic climate embodied in the combinations of their fields of study and universities. To examine these issues, we use data from a unique Dutch survey (WO-Monitor) designed to collect detailed information on graduates' transition from school to work. Since the data exclusively concern graduates from Dutch universities interviewed approximately 18 months after graduation, the allocation and adjustment processes in their early labour market careers can be analysed.

The results outline to what extent graduates from Dutch universities are continuing their careers in the Netherlands or abroad by working or pursuing a PhD. ${ }^{1}$ In line with expectations, we find that highly talented graduates more frequently opt for $\mathrm{PhD}$ study, which is positively correlated with their international mobility. However, being highly able increases the probability of moving abroad for work as well, although to a lesser extent than for a $\mathrm{PhD}$ degree. Consequently, highly able graduates are significantly more likely to go abroad than average graduates. Further, the graduates' investments in a migratory move and $\mathrm{PhD}$ study are associated with the climates embodied in certain fields of study and universities promoting going abroad and starting $\mathrm{PhD}$ study, respectively. These results are robust against alternative model specifications and alternative definitions of ability and climate.

This article is structured as follows. Section 2 introduces the theoretical framework of our analysis. Section 3 discusses the data set, and Section 4 deals with our econometric approach, taking into account the simultaneity of migration and $\mathrm{PhD}$ decisions. Section 5 presents the marginal effects of bivariate probit estimations, and Section 6 checks the robustness of the model and provides some extensions of the basic analyses. Section 7 concludes the article.

\section{Theoretical Considerations}

In response to increased international policy attention on the importance of knowledge and knowledge-generating persons for economic growth, we examine the destination of the

1 Throughout this article we consider PhD students as participating in education, although the majority of PhD students in the Netherlands formally have an employee status. Moreover, when we refer to graduates, we mean recent graduates, that is, young workers who graduated approximately within the past 18 months. 
highly able native students graduating from Dutch universities. If emigrating, Dutch society runs the risk of missing the returns on the investments made in the educational careers of these high potentials. This would be a brain drain.

Although the term brain drain is often reserved to describe the flows of highly skilled people from developing to developed countries (Lien and Wang 2003), it is not necessarily restricted to these flows. Davenport (2004, p. 618) defines brain drain as 'the departure at an appreciable rate of the most talented'. Docquier and Rapoport (2012) show that the emigration of highly skilled people from European countries (including the Netherlands) to the USA is biased to the most highly qualified, that is, graduates with a PhD degree or science and technology workers. In our case, brain drain refers to the emigration of recent native university graduates from the Netherlands, particularly those with the highest final exam results and those investing in a $\mathrm{PhD}$ degree.

Since education is understood to be a key determinant of long-term growth (Lucas 1988), brain drain can be considered detrimental to the source country. More precisely, the negative externality on the population left in the source country is due to the economywide decrease in the average level of human capital, which will slow down technological progress and hamper innovation. For developing countries, Bhagwati and Hamada (1974) show that labour market rigidities raise unemployment for all workers, with highly skilled workers bargaining for higher wages due to international competition and with the low skilled adjusting their wage demands upwards in response. Other papers refer to scale economies of education in the destination country (Miyagiwa 1991) and imperfect information for employers in the source country about the skills of the students who left to be trained in more developed destination countries (Kwok and Leland 1982). These papers imply that the most skilled leave without returning and that brain drain increases the welfare of rich countries at the expense of poor countries.

The recent literature is more optimistic about the benefits of brain drain for source countries. Beine et al. (2011) and Docquier and Rapoport (2012) argue that better migration prospects in potential destination countries could provide an incentive to young people in source countries to increase their investment in education. According to Docquier and Rapoport (2012, p. 698), 'migration prospects raise the expected return to human capital, thus inducing more people to invest (or people to invest more) in education at home'. This may hold for both developing and developed countries. ${ }^{2}$ The migration prospects in the USA for the most talented in Europe are based on higher investments in R\&D, higher wages in R\&D sectors of industry, and a better academic climate in the USA relative to Europe. This provides incentives for students in Europe to invest in science and technology education. However, highly skilled graduates from a particular European country may migrate within Europe as well, as Constant and D'Agosto (2010) demonstrate for Italy. Whether they go to the USA/Canada, the UK, or another European Union (EU) country depends on

2 Katz and Rapoport (2005) show that increased volatility in the domestic returns to education in developing countries may stimulate young people's further investments in human capital if they have the option to reduce volatility when emigrating. This so-called 'option value of education' could increase the average human capital level in a developing country, even after netting out the emigration of the highly skilled. Poutvaara (2008b), however, shows that conditionally on the shape of the production function, the sign of the effect of region-specific shocks on the investment in education, can be reversed. This is the case if the 3rd derivative of the production technology is equal to zero, like with a quadratic production technology, or negative. 
their personal background (field of study, working experience abroad, having finished a $\mathrm{PhD}$ ) and the availability of research funds in the destination country. However, distortions may arise when migration prospects differ per field of study. For example, Poutvaara (2008a) shows that countries could have an incentive to stimulate the provision of countryspecific education, such as law degrees, at the expense of internationally applicable education.

The increasing number of Dutch students going abroad for their master's or bachelor's studies (Richters et al. 2012) begs the question of whether increasing numbers of master's students are also going abroad after graduation. Returns to human capital abroad seem to be higher for workers trained at destination than for workers with similar formal qualifications trained at home (Coulombe and Tremblay 2009). Therefore, it may be profitable to migrate first as a student and find a job in the country of graduation afterwards. Oosterbeek and Webbink (2011) find that Dutch students who received a scholarship to study abroad indeed end up living abroad afterwards more often than other students. In addition, the number of months spent studying abroad increases the probability of migration. The authors correct for possible endogeneity bias in the variables for study abroad. The introduction of the Erasmus programme is found to have had similar effects on German students (Parey and Waldinger 2010). For the USA, Dreher and Poutvaara (2011) find that a larger number of foreign students increase subsequent immigration, implying a rise in the stock of immigrants and significant brain gain.

When students complete their master's studies, they can opt to continue their studies by entering a $\mathrm{PhD}$ programme or by entering the labour market and searching for a suitable job. The opportunities envisaged may also lie abroad. Whether to continue university education by enrolling in a $\mathrm{PhD}$ programme represents a human capital decision, since $\mathrm{PhD}$ study involves current costs for benefits expected sometime in the future (Mincer 1974; Becker 1975). The PhD track is attractive as long as the benefits over and above the benefits of a working life with only a master's degree outweigh the costs of investment in $\mathrm{PhD}$ study. Although highly able graduates may have higher forgone earnings from working in a regular job than average graduates, they will face lower costs because they have to exert less effort to complete their $\mathrm{PhD}$ and may have a better chance of just successfully completing the $\mathrm{PhD}$ programme. Hence, highly able graduates are more likely to pursue a $\mathrm{PhD}$ than others.

In addition, the move abroad of a master's graduate represents an investment decision that involves benefits and costs (Sjaastad 1962; Mincer 1978; Greenwood 1985). Once again, highly able graduates are more likely to invest in going abroad, since they need to spend less on gathering the required information on opportunities to work or study abroad and have a higher probability of finding a better-paying job abroad. This positive selection of migrants versus non-migrants with respect to skills increases with the skill-related difference in wages between the destination and source countries (Grogger and Hanson 2011). Furthermore, highly skilled migrants preferably sort into countries with high returns to skills. In addition, other factors, such as linguistic, cultural, and geographical proximity, influence the benefits and costs of the migration decision (Belot and Hatton 2012).

The decision to migrate is somewhat different for graduates who opt for PhD study than for those who choose to work, because they are not ending their academic career but, instead, are looking for the best place to continue it. After all, graduates opting for a $\mathrm{PhD}$ track will weigh the costs and benefits of PhD study abroad against the costs and benefits of pursuing a $\mathrm{PhD}$ in the Netherlands. Highly able graduates may expect higher returns from going abroad, since they are more likely than other graduates to obtain a $\mathrm{PhD}$ position 
at a highly reputable foreign university with an excellent research climate (Constant and D’Agosto 2010; Docquier and Rapoport 2012).

When analysing both investment decisions, we control for the study environment, which may stimulate graduates to continue their careers where their talents are most appreciated. This implies that graduates may be given a head start in terms of information or concrete alternatives. The climatic aspects this article takes into account are the internationalization of studies and the scientific character of studies, which are further discussed below.

Exchange programmes were established by the European Commission in the late 1980s to stimulate the international mobility of university students in internships or as part of their study abroad (for example, the Erasmus/Socrates grant). ${ }^{3}$ More importantly, in 1999, the ministers of education of 29 European countries signed the Bologna Declaration to establish a European Higher Education Area to increase the world competitiveness of the European system of higher education. Due to the Bologna process, the European model of higher education converged towards the successful American model (Malamud 2010). It increased external recognition and facilitated student mobility by assuring greater homogenization between degree programs (undergraduate and graduate) and better transferability of course credits between European higher educational institutions. In addition, many universities in Europe, in particular in the Netherlands, have invested greatly in the internationalization of university education. Some master's programmes at Dutch universities are even offered completely in English. Not only has the structure of higher education become more 'Americanized', but also research has become more focused on topics from abroad, with doctoral dissertations written in English as the new lingua franca and publication in US and other English language journals (Borghans and Cörvers 2010).

This internationalization is expected to have a positive effect on the decision to go abroad after graduation. After all, individuals are thus better informed about working or studying abroad and may have improved their knowledge of foreign languages, whereas psychological thresholds limiting their ability to go abroad are reduced. Consequently, we control for the international climate embodied by certain master's studies at universities when analysing the decision of graduates from these studies to go abroad. In addition, obtaining a $\mathrm{PhD}$ position may be more common in some fields of study or universities than in others, since some focus more on education, while others concentrate more on scholarly work (Borghans and Cörvers 2010). These differences have an impact on the extent to which students are prepared to participate in the $\mathrm{PhD}$ track. More importantly, these differences will also influence the number of available $\mathrm{PhD}$ positions for graduates at a university's particular department. Therefore, we include the $\mathrm{PhD}$ climate as a control variable in the decision of graduates to start $\mathrm{PhD}$ study. Since studies in which PhDs are common often have an international orientation and an international network of contacts, this may stimulate graduates who wish to invest in $\mathrm{PhD}$ study to consider doing so abroad and those who would like to go abroad to invest in PhD study. Therefore, both climate factors could play a role in the migration decision, as well as in the $\mathrm{PhD}$ decision.

We focus on the transition of recent graduates from Dutch universities to a job or a $\mathrm{PhD}$ position in or outside the Netherlands. Due to limitations in our data set, we were unable to study the return migration of graduates who acquired new skills abroad or the possible inflow of the highly talented from foreign countries to the Netherlands. We do, however,

3 See Borghans and Cörvers (2010) for trends of students leaving Western European countries, including the Netherlands, to study abroad. 
take into account that the decisions to enrol in $\mathrm{PhD}$ studies and to go abroad are simultaneous decisions. Furthermore, we pay attention primarily to the role of the ability of graduates in investment decisions. In particular, we want to determine whether highly able graduates are not only more susceptible to starting a $\mathrm{PhD}$ programme, but also more susceptible to going abroad than others, in line with our theoretical considerations, controlling for the two academic climate variables mentioned before. We thus aim to determine whether the Netherlands is indeed losing its highly talented university graduates.

\section{Data and Descriptive Statistics}

The data used were obtained from a survey among all recent graduates who were master's students at Dutch universities during the six college years 2001/2002-2006/2007. The surveys were carried out approximately 18 months after graduation, which implies that our sample contains the survey years 2003-2008. ${ }^{4}$ All graduates of the 13 Dutch universities have been sent an internet questionnaire. E-mail addresses are provided by these universities. Reminders are sent to attain a required minimum response rate of about $40 \%$. The response rates for the successive years are between 39 and $48 \%$. These rates are relatively high compared to similar graduate surveys.

Our sample comprises recent university graduates at the beginning of their professional career, that is, working in a regular job or enrolling as a $\mathrm{PhD}$ student, excluding those in other education or without a job. Our sample consists of 37,989 Dutch recent graduates, $5 \%$ of whom decided to migrate abroad and $10 \%$ of whom decided to participate in a $\mathrm{PhD}$ track. Note that we define migration as the movement of a recent Dutch graduate to another country.

The data set provides information about the talents of the graduates in the form of their average master's degree grades over all subjects taken. The grades can range from 1 (lowest) to 10 (highest), with 6 being the passing grade. We use an average master's degree grade of 8 or higher as a measure of high ability, since in the Netherlands, this group of graduates is potentially eligible for the so-called cum laude (with honours) degree. ${ }^{5}$ The data set also provides the average school-leaving grades of these graduates acquired in pre-university education (that is, at high school). These grades have similar ranges as the master's degree grades and are averaged over all subjects taken in the final exam.

We analyse whether highly talented graduates are not only more susceptible to start $\mathrm{PhD}$ study but also more susceptible to go abroad than others. We specifically focus on Dutch graduates instead of also including non-Dutch graduates. Non-Dutch graduates are more likely to migrate to a new destination or to return to their home country; therefore, besides our main interest in a possible brain drain of Dutch highly talented, the inclusion of non-Dutch graduates would lead to heterogeneity within our sample. With respect to our sample of Dutch graduates, we include information about their having been born abroad, experience abroad, and having at least one parent who was born abroad.

Since we are modelling the decisions to go abroad and to pursue a $\mathrm{PhD}$, recent graduates can be distinguished along two lines. They can be either emigrants or non-emigrants, and

4 This survey was coordinated by the Research Centre for Education and the Labour Market (ROA) of Maastricht University. See Huijgen (2004) on the methodology and the response rates of the subsequent surveys.

5 We say potentially because supplementary conditions can vary between universities. 
Table 1. Characteristics of emigrants and non-emigrants and $\mathrm{PhD}$ and non-PhD students

\begin{tabular}{|c|c|c|c|c|c|}
\hline Characteristics & Emigrants & Non-emigrants & PhDs & Non-PhDs & Total \\
\hline \multicolumn{6}{|l|}{ Ability } \\
\hline Average master's degree grade & 7.52 & 7.33 & 7.71 & 7.29 & 7.33 \\
\hline Master's degree grade $\geq 8.0(\%)$ & 31.3 & 19.7 & 44.1 & 17.5 & 20.0 \\
\hline Average pre-university degree grade & 7.45 & 7.28 & 7.56 & 7.26 & 7.29 \\
\hline Pre-university degree grade $\geq 8.0(\%)$ & 31.4 & 20.7 & 38.3 & 19.2 & 21.0 \\
\hline \multicolumn{6}{|l|}{ Background } \\
\hline Age (years) & 26.6 & 27.1 & 25.9 & 27.2 & 27.0 \\
\hline Female $(\%)$ & 42.0 & 54.3 & 48.0 & 54.5 & 53.9 \\
\hline At least one parent is an immigrant (\%) & $2.2 *$ & $2.2^{*}$ & 1.5 & 2.3 & 2.2 \\
\hline Born abroad $(\%)$ & 3.6 & 1.7 & $1.9 *$ & $1.8 *$ & 1.8 \\
\hline Experience abroad (\%) & 80.4 & 40.5 & 54.5 & 40.4 & 41.9 \\
\hline \multicolumn{6}{|l|}{ Job } \\
\hline Going abroad (\%) & 100 & 0 & 8.0 & 3.2 & 3.7 \\
\hline Going abroad when highly able (\%) & 100 & 0 & 9.1 & 5.0 & 5.8 \\
\hline Pursuing a $\mathrm{PhD}(\%)$ & 21.6 & 9.5 & 100 & 0 & 9.8 \\
\hline Pursuing a PhD when highly able (\%) & 34.3 & 21.0 & 100 & 0 & 21.7 \\
\hline \multicolumn{6}{|l|}{$\begin{array}{l}\text { Average academic climate of graduate's } \\
\text { study - university combination }{ }^{\mathrm{a}}\end{array}$} \\
\hline Average climate to go abroad (\%) & 8.0 & 5.0 & 6.4 & 5.0 & 5.1 \\
\hline Average climate to pursue a $\mathrm{PhD}(\%)$ & 12.0 & 10.0 & 18.0 & 9.0 & 9.9 \\
\hline$N$ & 1353 & 36,636 & 3773 & 34,216 & 37,989 \\
\hline
\end{tabular}

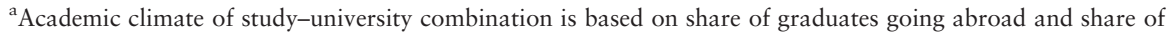
graduates pursuing a $\mathrm{PhD}$, respectively (see for calculation Supplementary Appendix A).

"Except for these two cases, all differences between the emigrant and non-emigrant groups and between the $\mathrm{PhD}$ and non-PhD groups were statistically different at the $5 \%$ level.

they can be $\mathrm{PhD}$ students or workers, that is, non-PhDs. Table 1 presents the personal characteristics of emigrants versus those of non-emigrants and of $\mathrm{PhDs}$ versus those of nonPhDs. Emigrants are more able (average master's degree grade 7.5 ) and participate more often in $\mathrm{PhD}$ studies $(22 \%)$ than graduates who stay in the Netherlands $(10 \%)$. In turn, $\mathrm{PhD}$ students are more able (average master's degree grade 7.7 ) and emigrate more often $(8 \%)$ than graduates who find a job (3\%). About one-fifth of the graduates are highly able, that is, have an average master's degree grade of 8 or higher. ${ }^{6}$ Among emigrants and particularly $\mathrm{PhD}$ students, the percentages of highly able recent graduates are much higher than the average.

Besides being more able, emigrants and particularly $\mathrm{PhDs}$ are younger than nonemigrants and non-PhDs, respectively. Furthermore, women are less likely to go abroad and/or participate in $\mathrm{PhD}$ studies than men. Moreover, emigrants are more likely than nonemigrants to have been born abroad $^{7}$ and to have experienced a period abroad during their studies. However, emigrants do not have parents who immigrated to the Netherlands more often than non-emigrants.

6 This is on a scale of 1-10. Grades should typically be 6 or higher to graduate. Pre-university (i.e. high school) degree grades are measured in the same way as master's degree grades.

7 Recall that all the graduates in our main analyses are Dutch, even when they were born abroad. 
The factors that proxy for the academic climate during master's studies to migrate abroad or to pursue a $\mathrm{PhD}$ are explained in Supplementary Appendix A. They are measured by the percentages of recent graduates, respectively, going abroad or pursuing a $\mathrm{PhD}$. Supplementary Table A.1 presents these percentages for all combinations of fields of study and universities (for example, graduates in the natural sciences of Utrecht University). ${ }^{8}$ As explained in the Supplementary Appendix, the climate variables of all recent individual graduates are calculated by excluding their decisions from the aggregate climate variable of their study-university combinations. This implies that the calculated percentages for the climate variables can vary between individual graduates. The average climate variables of all recent graduates are presented in the last few rows of Table 1 . The average climate variable indicating the international environment of the study-university combinations is highest for recent graduates who emigrated from the Netherlands, followed by recent graduates who became PhD students. Similarly, the PhD-conducive climate is highest for recent graduates who became PhD students and higher than average for those who emigrated.

High ability is our prior explanatory variable of interest for both the migration and the $\mathrm{PhD}$ decisions and is measured by the master's degree grades of recent graduates. Therefore we ask ourselves how comparable the shares of degrees of 8 and above across universities and specializations are as a measure of ability. The reasons for differences may be 3 -fold. First, these differences can be based on ('real' initial) abilities at the beginning of the master's study. This implies that students select themselves into particular combinations of fields of study and universities. Secondly, the learning processes and the competence levels that students achieve during their studies may differ between universities and fields of study. Thirdly, grading policies may vary across fields of studies and universities.

To analyse the impact of ability at the start of the master's study on the master's degree grade, we take the pre-university degree grade as a measure of ability at graduation. If we correct the master's degree grade for this measure of ability in a regression analysis, then remaining differences between the corrected master's degree grades should be based on either differences in grading policies or on differences in the acquired competences during the master's study. The corrected master's degree grade will be used in the robustness analysis of Section 6 (Table 5), that is, after Section 5 with the standard results.

In Table 2 we present the means, minima, and maxima of shares of degree grades equal to or higher than 8.0 by field of study. The shares refer to both uncorrected and corrected master's degree grades, and pre-university degree grades equal to or higher than 8.0. As explained above, we correct the master's degree grades by substituting these grades by the residuals of a regression analysis of the master's degree grades on the pre-university degree grades. The correlation coefficient between master's and pre-university degree grades for the total sample of recent graduates is 0.4 and statistically significant at the $1 \%$ level. Indeed, the mean shares of master's and pre-university degree grades of 8 and above are in line with each other for most fields of study, such as engineering, with high shares, and law, with low shares. A notable outlier is found for educational sciences, signalling the largest share of highly able graduates, notwithstanding the moderate inflow of students with preuniversity degree grades of 8 and above. Furthermore, an issue of concern is the wide range

8 Our sample consists of 13 universities. However, no information on whether graduates were born abroad is available for Leiden University. Therefore, we did not include graduates of Leiden University in our sample and 12 universities remained for the analyses. Moreover, only studyuniversity combinations with at least 25 graduates in the sample were taken into account. 
Table 2. Means, minima, and maxima of shares of degree grades equal to or higher than 8.0 by field of study

\begin{tabular}{|c|c|c|c|c|c|}
\hline \multirow[t]{2}{*}{ Field of study } & \multirow{2}{*}{$\begin{array}{l}\text { Correction for } \\
\text { pre-university } \\
\text { degree grade }^{a}\end{array}$} & \multicolumn{2}{|c|}{$\begin{array}{l}\text { Master's degree grade, uncorrected } \\
\text { (standard) and corrected (\%) }\end{array}$} & \multicolumn{2}{|c|}{ Pre-university degree grade $(\%)$} \\
\hline & & Mean share & $\begin{array}{l}\text { Range Minimum- } \\
\text { maximum at } \\
\text { different } \\
\text { universities }\end{array}$ & Mean share & $\begin{array}{l}\text { Range Minimum- } \\
\text { maximum at } \\
\text { different } \\
\text { universities }\end{array}$ \\
\hline \multirow[t]{2}{*}{ Natural sciences } & No & 23.97 & {$[6.76-34.20]$} & 29.23 & {$[12.16-38.66]$} \\
\hline & Yes & 12.27 & {$[4.73-17.80]$} & & \\
\hline \multirow[t]{2}{*}{ Engineering } & No & 32.78 & {$[20.00-45.95]$} & 35.36 & {$[34.00-42.11]$} \\
\hline & Yes & 16.49 & {$[5.00-21.62]$} & & \\
\hline \multirow{2}{*}{$\begin{array}{l}\text { Agricultural } \\
\text { sciences }^{\mathrm{b}}\end{array}$} & No & 23.27 & [23.27-23.27] & 23.83 & [23.83-23.83] \\
\hline & Yes & 10.43 & [10.43-10.43] & & \\
\hline \multirow[t]{2}{*}{ Medical sciences } & No & 20.97 & [11.97-28.51] & 24.46 & [17.14-33.80] \\
\hline & Yes & 9.07 & [5.91-14.30] & & \\
\hline \multirow[t]{2}{*}{ Social sciences } & No & 17.71 & [8.99-29.25] & 14.63 & {$[8.65-24.48]$} \\
\hline & Yes & 9.52 & {$[5.02-14.80]$} & & \\
\hline \multirow[t]{2}{*}{ Humanities } & No & 30.12 & {$[16.16-37.45]$} & 25.76 & {$[12.17-33.52]$} \\
\hline & Yes & 15.35 & [7.43-20.43] & & \\
\hline \multirow[t]{2}{*}{ Economics } & No & 13.43 & [7.59-20.21] & 21.07 & {$[14.64-32.54]$} \\
\hline & Yes & 5.79 & [3.31-9.56] & & \\
\hline \multirow[t]{2}{*}{ Law } & No & 11.32 & [3.59-20.61] & 15.63 & [12.54-19.43] \\
\hline & Yes & 5.81 & [1.39-10.62] & & \\
\hline \multirow{2}{*}{$\begin{array}{l}\text { Educational } \\
\text { sciences }\end{array}$} & No & 35.38 & [20.00-45.05] & 21.78 & {$[21.05-22.41]$} \\
\hline & Yes & 15.66 & [7.69-17.58] & & \\
\hline
\end{tabular}

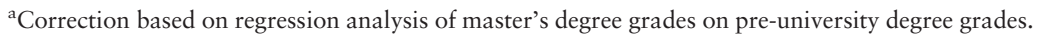

${ }^{b}$ There is no variation in degree grades because agricultural sciences can only be studied at Wageningen University.

of shares of what we call highly able graduates at different universities. For the same fields of study, the differences between the maximum and minimum values of the shares of these so-called highly able graduates are often around 20 percentage points.

As shown in Table 2, the differences in shares of master's degree grades of 8 and above decrease greatly when the master's degree grades are corrected for pre-university degree grades. The range between the maximum and minimum values of shares drops from around 20 percentage points to 10 percentage points. This indicates that the wide ranges in the shares of master's degree grades of 8 and above are indeed largely based on differences in (real initial) ability. The remaining differences in the master's degree grades of graduates may be based on differences in grading policies or on the human capital acquired during the master's programme.

From Table 2 we conclude that the (uncorrected) master's degree grade of recent graduates is a good measure of ability. The significant correlation between pre-university and (uncorrected) master's degree grades can be interpreted as evidence that differences in grading at universities are based at least partly on real ability differences (measured by the preuniversity degree grade). The uncorrected master's degree grade will be used as the main 
Table 3. Means, minima, and maxima of universities' climate variables by field of study ${ }^{a}$

\begin{tabular}{|c|c|c|c|c|}
\hline \multirow[t]{2}{*}{ Field of study } & \multicolumn{2}{|c|}{$\begin{array}{l}\text { Average climate of graduates } \\
\text { going abroad }(\%)\end{array}$} & \multicolumn{2}{|c|}{$\begin{array}{c}\text { Average climate of graduates } \\
\text { pursuing a } \mathrm{PhD}(\%)\end{array}$} \\
\hline & Mean & $\begin{array}{l}\text { Range Minimum- } \\
\text { maximum at } \\
\text { different } \\
\text { universities }\end{array}$ & Mean & $\begin{array}{l}\text { Range Minimum- } \\
\text { maximum at } \\
\text { different } \\
\text { universities }\end{array}$ \\
\hline Natural sciences & 4.66 & {$[1.84-7.22]$} & 31.70 & {$[3.80-45.73]$} \\
\hline Engineering & 6.30 & [1.59-8.67] & 22.89 & {$[9.42-37.65]$} \\
\hline Agricultural sciences ${ }^{\mathrm{b}}$ & 15.74 & [15.74-15.74] & 21.39 & [21.39-21.39] \\
\hline Medical sciences & 2.36 & {$[0.71-5.04]$} & 16.90 & [10.65-21.21] \\
\hline Social sciences & 4.74 & [1.14-27.15] & 7.76 & {$[3.53-25.25]$} \\
\hline Humanities & 6.68 & [1.84-26.64] & 6.17 & [2.66-10.31] \\
\hline Economics & 6.41 & [1.80-29.91] & 3.05 & {$[1.76-6.33]$} \\
\hline Law & 2.41 & {$[0.47-8.50]$} & 2.53 & {$[1.62-4.04]$} \\
\hline Educational sciences & 0.84 & {$[0.00-2.51]$} & 2.51 & {$[0.00-6.02]$} \\
\hline
\end{tabular}

${ }^{a}$ Climate variables based on share of graduates going abroad and share of graduates pursuing a $\mathrm{PhD}$, respectively (see for calculation Supplementary Appendix A).

${ }^{\mathrm{b}}$ There is no variation for the two climate variables because agricultural sciences can only be studied at Wageningen University.

explanatory variable in our standard regression analysis. However, aberrant grading policies for some fields of study and universities cannot be excluded. Therefore, we perform robustness checks when estimating the impact of ability on going abroad or pursuing a $\mathrm{PhD}$ by using the corrected master's degree grade of recent graduates as one of our alternative measures for the high ability of recent graduates.

The climate variables can also vary considerably between fields of study, as shown in Table 3. The agricultural sciences have the most conducive climate for recent graduates going abroad. The climate promoting going abroad is weakest for the medical sciences, law, and certain educational sciences. The differences between universities with respect to an academic climate conducive to going abroad can be very large, particularly in the case of the social sciences, humanities, and economics. The natural sciences most stimulate an academic climate that promotes participation in $\mathrm{PhD}$ programmes, followed by engineering, the agricultural sciences, and the medical sciences. Note that the differences between universities with respect to their academic climates to pursue a $\mathrm{PhD}$ are very large for the natural sciences, engineering, and social sciences.

To further explore the self-selection of students into particular fields of study and universities, we calculate the correlation coefficients between the climate factors promoting either going abroad or pursuing a $\mathrm{PhD}$ and various characteristics of the graduates. ${ }^{9}$ The correlation coefficients are presented in Table B.1 of Supplementary Appendix B. The correlations with pre-university grades are quite low $(0.1)$. The correlations with having been

9 Nevertheless, students may be self-selected along unobserved characteristics. Therefore, the endogeneity of the climate variables can bias the estimation of the impact of the climate variables on going abroad or pursuing a PhD. 
born abroad or at least one parent having been born abroad are also not higher than 0.1. However, these mostly significant correlations seem to indicate only a very moderate selfselection of students with respect to their choice for the international or scientific climate of particular fields of study or universities. The correlation is somewhat higher (0.2) between the climate promoting going abroad and the experience abroad of recent graduates during their studies. In this case, the correlation may result from both self-selection and the international climate of study-university combinations stimulating students to go abroad for their studies.

\section{Estimation Strategy}

We assume that the decisions to go abroad and to invest in a $\mathrm{PhD}$ are simultaneously made. We estimate these choices by bivariate probit analysis (for example, Greene 2003). We do not assume either of these choices is made first. Both decisions may be affected by similar unobserved background characteristics. The binary choices between going abroad and staying in the Netherlands and between pursuing a $\mathrm{PhD}$ and working are each generated by a probit equation whose errors are assumed to be correlated. Accordingly, the two probit equations are estimated simultaneously, which is efficient and gives the correlation between the two binary decisions.

Let $M_{i}$ be the dummy that denotes that graduate $i$ is moving abroad, and let $P h D_{i}$ be the dummy that denotes that graduate $i$ is pursuing a $\mathrm{PhD}$. We consider the following system of interrelated equations:

$$
\begin{aligned}
& M_{i}^{*}=\gamma_{1} \mathbf{A}_{i}+\gamma_{2} \mathbf{W}_{i}+\gamma_{3} \mathbf{C}_{i}+\epsilon_{1 i} \\
& M_{i}=1 \text { if } M_{i}^{*}>0 \text { and } M_{i}=0 \text { otherwise } \\
& P h D_{i}^{*}=\delta_{1} \mathbf{A}_{i}+\delta_{2} \mathbf{W}_{i}+\delta_{3} \mathbf{C}_{i}+\epsilon_{2 i} \\
& P h D_{i}=1 \text { if } P h D_{i}^{*}>0 \text { and } P h D_{i}=0 \text { otherwise }
\end{aligned}
$$

with

$$
E\left(\epsilon_{1 i}\right)=E\left(\epsilon_{2 i}\right)=0 ; \quad \operatorname{var}\left(\epsilon_{1 i}\right)=\operatorname{var}\left(\epsilon_{2 i}\right)=1 ; \quad \operatorname{cov}\left(\epsilon_{1 i}, \epsilon_{2 i}\right)=\rho \neq 0
$$

where $\mathbf{A}_{i}$ represents ability as the main explanatory variable, measured by the average master's degree grade of graduate $i ; \mathbf{W}_{i}$ is an observed vector of exogenous controls ${ }^{10} ; \gamma_{1}, \gamma_{2}$, and $\gamma_{3}$ are vectors of parameters that determine migratory movements; $\delta_{1}, \delta_{2}$, and $\delta_{3}$ are vectors of parameters that influence $\mathrm{PhD}$ participation; and $\mathrm{C}_{i}$ is a vector of institutional

10 Note that $\mathbf{A}_{i}, \mathbf{W}_{i}$, and $\mathbf{C}_{i}$ are defined similarly in both probit equations. The bivariate probit model in this article is a type of seemingly unrelated regression (SUR) model, since the errors are correlated and the regressors are identical, not restricted, and do not include endogenous variables. The estimated coefficients in linear single-equation ordinary least squares estimations with identical regressors in the set of equations have been shown to be efficient (Greene 2003) and equal to the estimated coefficients in the multivariate linear SUR model. However, due to the non-linearity of the probit equations in this article, the estimated coefficients in the SUR-type model are not, per se, equal to the coefficients estimated in the univariate probit equations. 
controls that capture both the climate promoting going abroad and the climate to pursue a $\mathrm{PhD}$ for a graduate's study-university combination (see the previous section).

The observed vectors of exogenous variables in equations (1) and (2) include personal characteristics that explain the investment behaviour of graduates after leaving university and comprise attributes such as ability (indicated by average master's degree grades), gender, age, foreign background, work and/or study experience acquired abroad during the study period, and cohort effects (that is, year of survey). The attributes reflect individuals' human capital, which determines the expected costs and benefits of the investment decisions to go abroad and/or to start a $\mathrm{PhD}$ programme. We add the average pre-university degree grade to (partially) control for the self-selection of students into study-university combinations (see the previous section).

To estimate equations (1) and (2) efficiently-similar to estimating SUR models-we take the potential joint probability of $\mathrm{M}$ and $\mathrm{PhD}$ into account by allowing $\epsilon_{1 i}$ and $\epsilon_{2 i}$ to be correlated $(\rho)$, which is accomplished by using a bivariate joint distribution. The equations are estimated by the full-information maximum likelihood method by using the biprobit command of the econometric software package Stata 12 (StataCorp 2011).

\section{Estimation Results}

The estimated marginal effects of the bivariate probit models of the choices between migrating and staying in the Netherlands and between pursuing a $\mathrm{PhD}$ and working are presented in Table 4. Panel A shows the marginal effects on the migration decision for the sample of recent Dutch graduates, and Panel B presents the marginal effects on their $\mathrm{PhD}$ decision.

Each marginal effect includes the direct effect of the estimated probit equation and the indirect effect of the other probit equation. The marginal effects in Table 4 represent the sum of the direct and indirect changes of the probability of migrating or continuing in a $\mathrm{PhD}$ track resulting from a unit change in the explanatory variable. The marginal effects on the migration and $\mathrm{PhD}$ decisions can be interpreted as (quasi-)elasticities evaluated at the means of the explanatory variables (Greene 1996; Christofides et al. 1997, 2000). The dummy variables are set to one instead of zero to calculate the marginal effects. The dummy variables are set to one if the grade is above 8 (that is, high ability), the individual is female, at least one parent is an immigrant, the individual was born abroad, the individual has work and/or study experience abroad, or if the year of the survey is later than 1996. The variables that proxy for the academic climate of a field of study at the university of graduation are measured in percentages, unlike the individual attributes, which are all dummy variables (except for age). We discuss our findings of the estimated probit equations in two steps: first, the results of the migration equation and, second, the results of the decision to pursue a $\mathrm{PhD}$. We are mainly interested in the effect of ability on migration and $\mathrm{PhD}$ participation, thereby controlling for the effect of a stimulating climate at the university to go abroad or enrol into a PhD track.

The estimation results of the migration choice show that ability, indicated by the average master's degree grade, has a significant and positive effect on migration: Highly able graduates who leave the university have a $1.38 \%$ higher probability of going abroad than recent graduates who scored below 8 . Females have a $1.5 \%$ lower probability of emigrating 
Table 4. Marginal effects on migration and $\mathrm{PhD}$ decisions

\begin{tabular}{|c|c|c|}
\hline Explanatory variables $^{\mathrm{a}}$ & Coefficient & Standard error \\
\hline \multicolumn{3}{|l|}{ Panel A: Migration decision } \\
\hline Average master's degree grade $\geq 8$ & $0.0138 * *$ & 0.0029 \\
\hline Average pre-university grade $\geq 8$ & $0.0096 * * *$ & 0.0027 \\
\hline Female & $-0.0147 * * *$ & 0.0021 \\
\hline Age in years & -0.0005 & 0.0003 \\
\hline At least one parent an immigrant & 0.0005 & 0.0080 \\
\hline Born abroad & $0.0234 * *$ & 0.0093 \\
\hline Experience abroad & $0.0565 * * *$ & 0.0029 \\
\hline \multicolumn{3}{|c|}{ Climate of study-university combination ${ }^{b}$} \\
\hline To go abroad & $0.0012 * * *$ & 0.0001 \\
\hline To pursue a $\mathrm{PhD}$ & $0.0002 *$ & 0.0001 \\
\hline \multicolumn{3}{|l|}{ Panel B: PhD decision } \\
\hline Average master's degree grade $\geq 8$ & $0.1078 * * *$ & 0.0058 \\
\hline Average pre-university grade $\geq 8$ & $0.0339 * * *$ & 0.0043 \\
\hline Female & $-0.0175 * *$ & 0.0032 \\
\hline Age in years & $-0.0099 * * *$ & 0.0007 \\
\hline At least one parent an immigrant & -0.0107 & 0.0105 \\
\hline Born abroad & 0.0054 & 0.0120 \\
\hline Experience abroad & $0.0216 * * *$ & 0.0035 \\
\hline \multicolumn{3}{|c|}{ Climate of study-university combination ${ }^{b}$} \\
\hline To go abroad & -0.0004 & 0.0003 \\
\hline To pursue a $\mathrm{PhD}$ & $0.0065 * *$ & 0.0002 \\
\hline Correlation $(\rho)$ & $0.1627 * * *$ & \\
\hline $\mathrm{N}$ & 37,989 & \\
\hline Log likelihood & $-11,434.271$ & \\
\hline McFadden pseudo- $R^{2}$ & 0.1570 & \\
\hline
\end{tabular}

${ }^{\mathrm{a}}$ Year dummies are not shown in the table.

${ }^{\mathrm{b}}$ Based on share of graduates going abroad and share of graduates pursuing a $\mathrm{PhD}$, respectively (see for calculation Supplementary Appendix A).

"Significant at the $10 \%$ level, $*$ significant at the $5 \%$ level, $* *$ significant at the $1 \%$ level.

than males. Having an international background, as measured by having been born abroad or having experience abroad, also increases the probability of emigration.

Our findings on the climate variables indicate that graduating in an atmosphere in which more fellow students go abroad is positively associated with the probability of emigration. Although the effect may not be fully causal and the estimated coefficient could be biased due to the endogeneity of the climate variables, an increase of a unit in the variable for a climate promoting going abroad (that is, a change of 1 percentage point) increases the probability of going abroad by $0.12 \%$. This may not seem to have very much impact, but differences in climates between study-university combinations can amount to 25 percentage points or more, as shown in Table 3. A climate promoting the pursuit of a $\mathrm{PhD}$ has hardly any impact on the decision to emigrate.

Our findings reveal a strong positive effect of almost $11 \%$ for the ability of graduates, as indicated by a high average master's degree grade, on estimated $\mathrm{PhD}$ choices. A high 
average pre-university grade further increases this probability by $3 \%$. For females and older graduates, the probability of enrolling in a PhD track is lower than for males and younger graduates.

The climate variable for migration has no significant effect on the $\mathrm{PhD}$ choice, whereas the climate variable for the pursuit of a $\mathrm{PhD}$ is positively associated with $\mathrm{PhD}$ choice. The latter effect is rather large, with a $0.65 \%$ change for a $1 \%$ increase in the climate variable, although it could be biased due to endogeneity. The differences between study-university combinations with respect to $\mathrm{PhD}$ climate are even greater than for a climate promoting going abroad, as can be seen from Table 3.

Summarizing, we find that highly able graduates have a strong preference for pursuing $\mathrm{PhD}$ studies instead of working, which is correlated with their over-representation in the flow of graduates going abroad. Additionally, we find that factors that proxy for academic climates conducive to emigrating after graduation and to continuing in a $\mathrm{PhD}$ track play a significant role in the decisions to migrate and to pursue a $\mathrm{PhD}$, respectively.

\section{Extensions and Further Tests}

To test the robustness of our model, we consider other specifications as well. First, we focus on the simultaneous character of the estimated model. The results are presented in Supplementary Appendix C, Table C.1. Two separate probit equations are estimated for the choice between going abroad and participating in $\mathrm{PhD}$ studies, neglecting the fact that both choices are simultaneously decided upon. A univariate probit model is generated to scrutinize the equations' simultaneity. Our results indicate that the estimates for the univariate model hardly differ from the estimates obtained when taking into account simultaneity.

Furthermore, we include dummy variables for the fields of study and universities instead of the climate variables for going abroad and pursuing a PhD. The results are presented in Supplementary Table C.2. The results show that, in particular, the impact of ability on the migration decision drops when using all the dummy variables for fields of study and universities (including the interaction terms) as explanatory variables. This implies that the real marginal effect of ability on migration may be about $40 \%$ lower than suggested in the standard estimation equation. Including the dummy variables also increases the correlation coefficient $(\rho)$ and the estimated fit (measured by the log likelihood) relative to the bivariate probit estimations with the two climate variables. Although we should take the drop in the impact of ability and the better fit seriously, we argue that it is still useful to estimate the coefficients of the climate variables, since they have a clear meaning. On the contrary, the dummy variables can capture very different characteristics of fields of study and universities without revealing the reasons for the differences in impact.

Additionally, in Supplementary Table C.3, we present the marginal effects of including the interaction term of both climate variables. Now the impact of ability on the migration and $\mathrm{PhD}$ decisions hardly changes. However, the marginal effects of the climate variables on these decisions look rather different relative to the standard estimation equation. When we evaluate the association between the migration decision with the climate to go abroad at the respective means of the climate variables (about 5 and $10 \%$ ), we find that about half of this association is imparted via the interaction term, thus via a climate promoting the pursue of a PhD investment abroad. The results also show that the decision to emigrate is 
negatively associated with the climate to pursue a $\mathrm{PhD}$. For the $\mathrm{PhD}$ decision, we find a much smaller estimated coefficient of the interaction term, relative to the main effect of the climate to pursue a $\mathrm{PhD}$. In addition, here, the probability of pursuing a $\mathrm{PhD}$ is negatively associated with a positive migration climate.

In Supplementary Table C.4, we check the robustness of the results with respect to the pre-university grade. The pre-university grade is taken into account as an additional explanatory variable to correct for possible endogeneity of the climate variables with respect to ability. Excluding the pre-university grade variable increases the estimated coefficient of the master's degree grade, because it now incorporates the ability effect of the preuniversity degree grade as well.

Equally interesting are the results for the estimated coefficients of the climate variables for this robustness check. Supplementary Table C. 4 shows that these hardly change when the pre-university grade is excluded from the regression. This provides further evidence, next to the low correlations between the climate variables and the pre-university degree grade discussed in Section 3, that the estimated coefficients of the climate variables are not very much influenced by self-selection with respect to ability.

However, unobserved student characteristics could still play a role. If they do, then the estimation coefficients for the impact of the climate variables on $\mathrm{PhD}$ and migration decisions may suffer from an endogeneity bias. We perform another robustness analysis to control for self-selection with respect to ability. A good proxy for self-selection may be the share of top students at the different study-university combinations. The climate to attract top students has been calculated in the same way as the two other climate variables. This is explained in Supplementary Appendix A. Although the climate to attract top students can vary considerably across study-university combinations (see Supplementary Appendix A), including this climate variable as an additional explanatory variable hardly influences the estimation coefficients of the two other climate variables. This is shown by Table C.5 in Supplementary Appendix C. Likewise, the impact of ability on going abroad or pursuing a PhD does hardly change. Supplementary Table C.5 also shows that the climate to attract top-students variable has only a small and marginally significant effect on migration.

Furthermore, since the focus of this article is on the impact of ability on going abroad or pursuing a PhD, we include Table 5 to present an overview of the estimated coefficients for ability under alternative specifications of our estimation model. In the top part of the table, we show the results that were previously discussed. Apart from this, we add different measures of ability to check the robustness of the impact of ability on the migration and $\mathrm{PhD}$ decision.

First, we note our focus on only Dutch graduates. An alternative estimation was carried out by including non-Dutch graduates and the results hardly differ from those obtained for the estimation of only Dutch graduates. Next, we use different measures of ability. ${ }^{11}$ It turns out that the marginal effects on emigration or $\mathrm{PhD}$ increase if the selection criterion for high ability is stronger. Both marginal effects become almost thrice as large if the

11 Full estimation results of variants discussed in this paragraph are not presented in Supplementary Appendix $\mathrm{C}$, but are available from the authors on request. We also estimated variants excluding the recent graduates from Wageningen University, since all students at this university are in the field of agricultural sciences. The results from this variant do not differ much from the baseline results and are available on request as well. 
Table 5. Marginal effects of ability on migration and $\mathrm{PhD}$ decisions for alternative specifications and ability measures

\begin{tabular}{|c|c|c|}
\hline Specification and ability measure & $\begin{array}{l}\text { Effect of ability on } \\
\text { migrationdecision }\end{array}$ & $\begin{array}{l}\text { Effect of ability on } \mathrm{PhD} \\
\text { decision }\end{array}$ \\
\hline Univariate probits (Supplementary Table C.1) & $0.0137 * * *$ & $0.1078 * * *$ \\
\hline $\begin{array}{l}\text { Dummy variables for fields of study and universities } \\
\text { instead of climate variables(Supplementary } \\
\text { Table C.2, last column) }\end{array}$ & $0.0085 * * *$ & $0.1017 * * *$ \\
\hline $\begin{array}{l}\text { Including interaction term between climates of } \\
\text { study-university combination for going abroad } \\
\text { and pursuing a } \mathrm{PhD} \text { (Supplementary Table C.3) }\end{array}$ & $0.0136 * *$ & $0.1079 * * *$ \\
\hline $\begin{array}{l}\text { Excluding pre-university degree grade } \\
\text { (Supplementary Table C.4) }\end{array}$ & $0.0176 * * *$ & $0.1250 * * *$ \\
\hline $\begin{array}{l}\text { Including climate of study-university combination } \\
\text { to attract top students (Supplementary } \\
\text { Table C.5) }\end{array}$ & $0.0134 * * *$ & $0.1077 * * *$ \\
\hline Including non-Dutch recent graduates ${ }^{c}$ & $0.0129 * * *$ & $0.1113 * * *$ \\
\hline Average master's degree grade $\geq 7.0^{c}$ & $0.0112 * * *$ & $0.0529 * * *$ \\
\hline Average master's degree grade $\geq 7.5^{\mathrm{c}}$ & $0.0115^{* * *}$ & $0.0770 * * *$ \\
\hline $\begin{array}{l}\text { Average master's degree grade } \geq 8.0 \text { (standard, } \\
\text { Table 4) }\end{array}$ & $0.0138 * * *$ & $0.1078 * * *$ \\
\hline Average master's degree grade $\geq 8.5^{\mathrm{c}}$ & $0.0200 * * *$ & $0.2001 * * *$ \\
\hline Average master's degree grade $\geq 9.0^{c}$ & $0.0407 * * *$ & $0.2058 * * *$ \\
\hline $\begin{array}{l}\text { Average master's degree grade controlled for pre- } \\
\text { university degree grade (see Table 2) }\end{array}$ & $0.0159 * * *$ & $0.1305 * * *$ \\
\hline $\begin{array}{l}\text { Average master's degree grade: top } 20 \% \text { per study- } \\
\text { university combination }{ }^{c}\end{array}$ & $0.0134 * *$ & $0.1247 * * *$ \\
\hline
\end{tabular}

${ }^{a}$ Climate variables based on share of graduates going abroad and share of graduates pursuing a PhD, respectively (see for calculation Supplementary Appendix A).

${ }^{\mathrm{b}}$ Climate variable based on share of graduates with pre-university degree grade $\geq 8$ (see for calculation Supplementary Appendix A).

'Estimates not included in Supplementary Appendix C but available on request.

***Significant at the $1 \%$ level.

average master's and pre-university degree grades are at least 9.0 instead of 8.0. With average degree grades of at least 6.5 , the effects become statistically insignificant.

Moreover, we try to prevent the impact of different grading policies between studyuniversity combinations by using two alternative measures for high ability. First, we use the master's degree grade corrected for the pre-university degree grade (that is, a proxy for real initial ability, see for further explanation Table 2 in Section 3) to estimate the impact on both the migration and $\mathrm{PhD}$ decisions. Interestingly, both marginal effects increase slightly, which is difficult to explain if the master's degree grades are based on differences in grading policies instead of ability at graduation. Finally, we select the top $20 \%$ of recent graduates per study-university combination instead of using the 8.0 threshold for the average master's degree grade, which applies to $20 \%$ of the recent graduates overall (see Table 1 in Section 3 ). We find that the marginal effect of the most able $20 \%$ per study-university combination on the migration and $\mathrm{PhD}$ decisions does not change relative to the standard estimation. 


\section{Discussion and Conclusion}

This article contributes to the discussion on brain drain within the advanced world. In response to increased international policy attention on the importance of knowledge and knowledgegenerating persons for economic growth, we focus on the highly able who graduate from Dutch universities. We analyse to what extent they are creamed off by other countries by examining the relation between their ability, indicated by their average master's degree grade, and their destination after graduation. After graduation, graduates can choose to either continue their academic career by investing in $\mathrm{PhD}$ study or enter the labour market and search for a job, taking into account that both options can be realized in the Netherlands as well as abroad. We consider the role of possible unobserved factors in the simultaneous decisions to pursue $\mathrm{ahD}$ and go abroad by assuming a correlation between the error terms in the bivariate probit model that generates these decisions. To estimate this model, we use a data set that considers the labour market position of Dutch graduates 18 months after graduation from universities in the Netherlands, that is, at the beginning of their professional career.

We find that the ability of recent graduates, as indicated by their master's degree grade, has a significant and positive effect on moving abroad. We also find that highly able graduates have a stronger preference for $\mathrm{PhD}$ study to working, which contributes to an over-representation of the highly able in the flow of graduates going abroad. The higher the ability of these graduates, the stronger the effects on moving abroad or pursuing a PhD. These findings remain significant under various specifications and ability measures. They indicate an outflow of the highly talented from the Netherlands to other countries.

Unfortunately, we have no information in our data set on their length of stay or possible return. We are therefore unable to study in depth the return migration. From other sources (for example, Finn 2014) we know that the majority of the Dutch graduates going abroad will stay there for longer than 5 years. It will be difficult for the Netherlands to recoup the educational investments made in these highly talented. On the other hand, this loss is compensated for by the returns of the highly talented foreign graduates who pursued a $\mathrm{PhD}$ in the Netherlands and subsequently become available for the Dutch labour market. Part of these international flows of students is only temporary because after graduation the majority will return home. Stay rates of foreign higher education graduates in the Netherlands are estimated at 19\% (Bijwaard 2010). For foreign PhD graduates in the Netherlands, stay rates are estimated at $32 \%$ (Rud et al. 2015). Stay rates of Dutch $\mathrm{PhD}$ graduates in foreign countries are probably higher, and their return rates consequently lower. Finn (2014) reports that $62 \%$ of European $\mathrm{PhD}$ graduates in the USA - a quite popular destination of Dutch $\mathrm{PhD}$ students ${ }^{12}$ - who received a doctorate degree in 2006, still were in the USA 5 years later.

The academic climate of the field of study at the university of graduation plays an important role in both the migration and $\mathrm{PhD}$ decisions. Since the climate variables may suffer from endogeneity, we include the pre-university grade in the regression analysis to control to some extent for self-selection with respect to ability in the climate variables. In an additional analysis, we try to account for self-selection by including the climate to attract top students. Our results are robust against excluding or including these explanatory variables in the regression analyses: the impact varies to a certain extent, but the coefficients always remain strongly significant. Our findings indicate that the odds of emigration are significantly positively associated with graduation in an atmosphere where more fellow students 
go abroad, particularly if there is an inspiring climate to invest in $\mathrm{PhD}$ study. Although a better climate for recent graduates to invest in a $\mathrm{PhD}$ study may increase the number of PhDs going abroad, the effect on the emigration of recent graduates may be negative. Furthermore, $\mathrm{PhD}$ participation generally goes hand in hand with an inspiring climate to invest in PhD study, but is negatively associated with a good migration climate.

From a policy perspective, we could argue that a small country such as the Netherlands could retain highly talented young academics by creating an academic environment with many graduates in $\mathrm{PhD}$ tracks. According to our results, improving the $\mathrm{PhD}$ climate could be an effective way of encouraging (highly able) graduates to pursue a $\mathrm{PhD}$ in the Netherlands. Of course, some of the additional $\mathrm{PhD}$ students will choose to study outside the Netherlands, but an improved $\mathrm{PhD}$ climate can attract more highly talented graduates from other countries too, which could compensate for this leakage abroad. With a focus on the Netherlands, retaining and attracting more recent graduates by creating an outstanding international and research climate, particularly for the highly talented, could improve the negative migration balance of the highly skilled with other Organisation for Economic Cooperation and Development countries. Many countries in the EU face such a negative balance, particularly because of the strong pull of the USA.

From an international perspective, we should be aware that better migration prospects in any destination country combined with the lower transaction costs of international migration (for example, due to the Bologna Declaration and the Americanization of European higher education) may provide additional incentives to young people from all over the world to increase their investment in education. Moreover, the international orientation of universities and participation in international scholar networks are essential for fundamental research. Only new scientific understandings that are internationally accepted and applied contribute to scientific reputation, the stock of knowledge, and world economic growth. If young, highly able graduates conducting $\mathrm{PhD}$ work or otherwise involved in the production and diffusion of knowledge move from one country to another, they could extend the boundaries of the exercise of scholarly work. International orientation and an international network of contacts in studies where $\mathrm{PhDs}$ are common provide incentives for young people to invest in their human capital and stimulate graduates who wish to continue their education by participating in $\mathrm{PhD}$ study to consider doing so abroad.

Another policy option may be better exploitation of the network and knowledge abroad of those who have left the home country. The return migration of these graduates may be valuable if their skills have been acquired more effectively abroad and are applicable and/or complementary in their home country (Dustmann et al. 2011). However, the focus should not be exclusively on the return of graduates who emigrated, since it can be very advantageous to keep in touch with graduates abroad to stimulate knowledge exchange, investments, and trade. Many Dutch universities nowadays have alumni circles around the world that organize activities locally, but are also invited to participate in events at their alma mater. These kinds of networks and exchanges could be further exploited, and can also serve as a good example for other countries.

\section{Acknowledgements}

Earlier versions of this paper were presented at the ROA Labour Workshop in September 2007 in Maastricht, the Transition in Youth 2007 Workshop in Ghent, the Migration 
Session at the 2007 EALE Conference in Oslo, the Spring 2008 Seminar Series of the Faculty of Spatial Sciences of the University of Groningen, the Second International Conference on Educational Economics in 2008 in Athens, and the 2012 CESifo Conference on International Migration in Munich. We would like to thank the participants of these sessions, as well as Lex Borghans, Marion Collewet, Denis de Crombrugghe, Andries de Grip, Christoph Meng, Margarida Rodrigues, editor Panu Poutvaara, and two anonymous referees for their helpful comments and discussions on earlier drafts of the paper. Thanks are also due to Erik Lintjens, who contributed to seminal versions of the paper.

\section{Supplementary material}

Supplementary material is available at Cesifo online.

\section{References}

Becker, G. S. (1975), Human Capital: A Theoretical and Empirical Analysis, with Special Reference to Education, 2nd ed, National Bureau of Economic Research, New York.

Beine, M., F. Docquier and Ç. Özden (2011), "Diasporas”, Journal of Development Economics $95,30-41$.

Beine, M., F. Docquier and H. Rapoport (2001), "Brain Drain and Economic Growth: Theory and Evidence", Journal of Development Economics 64, 275-89.

Belot, M. K. V. and T. J. Hatton (2012), "Immigrant Selection in the OECD", Scandinavian Journal of Economics 114, 1105-28.

Bhagwati, J. N. and K. Hamada (1974), "The Brain Drain, International Integration of markets for Professionals and Unemployment", Journal of Development Economics 1, 19-42.

Bijwaard, G. E. (2010), "Immigrant migration dynamics model for The Netherlands", Journal of Population Economics 23, 1213-47.

Black, G. C. and P. E. Stephan (2010), "The Role of Foreign Graduate Students and Postdoctoral Scholars", in C. T. Clotfelter, ed., American Universities in a Global Market, National Bureau of Economic Research, University of Chicago Press, Chicago; London, pp. 129-61.

Boeri, T., H. Brücker, F. Docquier and H. Rapoport, eds. (2012), Brain Drain and Brain Gain: The Global Competition to Attract High-Skilled Migrants, Reports for the Fondazione Rodolfo DeBenedetti, Oxford University Press, Oxford.

Borghans, L. and F. Cörvers (2010), "The Americanization of European Higher Education and Research", in C. T. Clotfelter, ed., American Universities in a Global Market, National Bureau of Economic Research, University of Chicago Press, Chicago; London, pp. 231-67.

Castells, M. (1996), The Information Age: Economy, Society and Culture - The Rise of the Network Society, I, reprinted 1999, Blackwell Publishers, Oxford.

Chellaraj, G., K. E. Maskus and A. Mattoo (2006), "Skilled Immigrants, Higher Education, and U.S. Innovation”, in Ç. Özden and M. Schiff, eds, International Migration, Remittances \& the Brain Drain, World Bank/Palgrave Macmillan, Washington; New York, pp. 245-59.

Christofides, L. N., J. W. Hardin and T. Stengos (2000), "Corrigendum to 'On the Calculation of Marginal Effects in the Bivariate Probit Model [Econ. Lett. 54, (1997) 203-08]”, Economics Letters 68, 339.

Christofides, L. N., T. Stengos and R. Swidinsky (1997), "On the Calculation of Marginal Effects in the Bivariate Probit Model", Economics Letters 54, 203-8.

Clotfelter, C. T. ed. (2010), American Universities in a Global Market, National Bureau of Economic Research, University of Chicago Press, Chicago; London. 
Coe, D. T. and E. Helpman (1995), "International R\&D Spillovers", European Economic Review 39, 859-87.

Constant, A. F. and E. D’Agosto (2010), “Where Do the Brainy Italians Go?”, in F. E. Caroleo and F. Pastore, eds, The Labour Market Impact of the EU Enlargement, A New Regional Geography of Europe? Physica-Verlag (Springer), Heidelberg, pp. 247-71.

Coulombe, S. and J. F. Tremblay (2009), "Migration and Skills Disparities across the Canadian ProvincesRegional Studies 43, 5-18.

CPB (2012), "De economische effecten van internationalisering in het hoger onderwijs", CPB Notitie 18 April, CPB Netherlands Bureau for Economic Policy Analysis, The Hague.

Davenport, S. (2004), "Panic and Panacea: Brain Drain and Science and Technology Human Capital Policy", Research Policy 33, 617-30.

Docquier, F. and H. Rapoport (2012), “Globalization, Brain Drain, and Development”, Journal of Economic Literature 50, 681-730.

Dreher, A. and P. Poutvaara (2011), "Foreign Students and Migration to the United States", World Development 39, 1294-307.

Dustmann, C., I. Fadlon and Y. Weiss (2011), "Return Migration, Human Capital Accumulation and the Brain Drain", Journal of Development Economics 95, 58-67.

Finn, M. (2014), Stay Rates of Foreign Doctorate Recipients from U.S. Universities, 2011, Oak Ridge Institute for Science Education, Oak Ridge, TN.

Greene, W. H. (1996), "Marginal Effects in the Bivariate Probit Model”, Working Paper EC-9611, Department of Economics, Stern School of Business, New York University, New York.

Greene, W. H. (2003), Econometric Analysis, 5th ed., Pearson International Edition, Prentice Hall, New Jersey.

Greenwood, M. J. (1985), "Human Migration: Theory, Models, and Empirical Studies”, Journal of Regional Science 25, 521-44.

Grogger, J. and G. H. Hanson (2011), "Income Maximization and the Selection and Sorting of International Migrants”, Journal of Development Economics 95, 42-57.

Gross, M. and N. Schmitt (2006), "Why Do Low- and High-Skill Workers Migrate, Flow Evidence from France”, Working Paper No. 1797, CESifo, Munich.

Harris, R. G. (2001), “The Knowledge-Based Economy: Intellectual Origins and New Economic Perspectives", International Journal of Management Reviews 3, 1-40.

Huijgen, T. (2004), “Methodiek Schoolverlatersinformatiesysteem 2003”, ROA Technical Report 2004/3, Research Centre for Education and the Labour Market, Maastricht.

Hunt, J. and M. Gauthier-Loiselle (2010), "How Much Does Immigration Boost Innovation?" American Economic Journal: Macroeconomics 2, 31-56.

Katz, E. and H. Rapoport (2005), “On Human Capital Formation with Exit Options”, Journal of Population Economics 18, 267-74.

Kwok, V. and H. Leland (1982), “An Economic Model of the Brain Drain”, American Economic Review 72, 91-100.

Lien, D. and Y. Wang (2003), "Brain Drain or Brain Gain: A Revisit", Journal of Population Economics 18, 153-63.

Lindley, R. M. (2002), “Knowledge-Based Economies: The European Employment Debate in a New Context", in M. J. Rodrigues, ed., The New Knowledge Economy in Europe: A Strategy for International Competitiveness and Social Cohesion, Edward Elgar, Cheltenham, pp. $95-145$.

Lucas, R. E. (1988), “On the Mechanics of Economic Development”, Journal of Monetary Economics 22, 3-42.

Machlup, F. (1962), The Production and Distribution of Knowledge in the United States, Princeton University Press, Princeton, NJ. 
Malamud, O. (2010), "The Structure of European Higher Education in the Wake of the Bologna Reforms", in C. T. Clotfelter, ed., American Universities in a Global Market, National Bureau of Economic Research, University of Chicago Press, Chicago; London, pp. 205-30.

Mincer, J. (1974), Schooling, Experience, and Earnings, National Bureau of Economic Research, New York.

Mincer, J. (1978), “Family Migration Decisions”, Journal of Political Economy 86, 749-73.

Miyagiwa, K. (1991), "Scale Economies in Education and the Brain Drain Problem", International Economic Review 32, 743-59.

Oosterbeek, H. and D. Webbink (2011), "Does Studying Abroad Induce a Brain Drain?" Economica 78, 347-66.

Parey, M. and F. Waldinger (2010), "Studying Abroad and the Effect on International Mobility: Evidence from the Introduction of Erasmus", Economic Journal 121, 194-222.

Park, J. (2004), "International Student Flows and R\&D Spillovers", Economics Letters 82, $315-20$.

Poutvaara, P. (2008a), "Public and Private Education in an Integrated Europe: Studying to Migrate and Teaching to Stay?”, Scandinavian Journal of Economics 110, 591-608.

Poutvaara, P. (2008b), "On Human Capital Formation With Exit Options: Comment and New Results”, Journal of Population Economics 21, 679-84.

Richters, E., S. Roodenburg and R. Kolster (2012), Mapping Mobility 2012, International Mobility in Dutch Higher Education, Nuffic, The Hague.

Rodrigues, M. J. ed. (2002), The New Knowledge Economy in Europe: A Strategy for International Competitiveness and Social Cohesion, Edward Elgar, Cheltenham.

Rud, I., B. Wouterse and R. van Elk (2015), Stay rates of foreign PhD graduates in the Netherlands, СРB Background Document, September, СРB Netherlands Bureau for Economic Policy Analysis, The Hague.

Saint-Paul, G. (2008), "Brain Drain: Some Evidence from European Expatriates in the United States”, CESifo Forum 3, 19-25.

Sjaastad, L. A. (1962), "The Costs and Returns of Human Migration. Part 2: Investment in Human Beings", Journal of Political Economy 70, 80-93.

StataCorp (2011), Stata Statistical Software: Release 12, StataCorp LP, College Station, TX.

Stephan, P. E. and S. G. Levin. (2001), "Exceptional Contributions to US Science by the ForeignBorn and Foreign-Educated", Population Research and Policy Review 20, 59-79.

Stuen, E. T., A. M. Mobarak and K. E. Maskus. (2012), "Skilled Immigration and Innovation: Evidence from Enrollment Fluctuations in US Doctoral Progams”, Economic Journal 122, 1143-76.

Williams, A. M. (2006), "Lost in Translation? International Migration, Learning and Knowledge”, Progress in Human Geography 30, 588-607. 